\title{
Presença do Itamarati
}

Ñ̃o é a primeira vez que esta Revista se ocupa do Ministério das Relações Exteriores. Em diversas oportunidades, aqui se tem analisado a estrutura, as atividades e os objetivos dêsse órgão da administração pública, por tantos titulos colocado em posição de relêvo na vida nacional.

E não apenas dêle nos temos ocupado como igualmente dêle temos recebido inteligentes colaborações, assinadas por alguns dos seus mais legitimos representantes. Nossas relaçốes com o Itamarati não são, portanto, de hoje.

Por isso mesmo, ao voltarmos a falar sôbre êle, num momento em que muitos planos e muitas esperanças para êle convergem. sentimo-nos à vontade nesse reencontro para nós sempre grato e proveitoso.

É possivel que em outros países ocorra o mesmo fenômeno. No Brasil, no entanto, é fato de incontestável veracidade o prestigio que a diplomacia desfruta junto às elites e ao grande público. Não haverá entre nós, seguramente, conhecimento generalizado dos problemas de relaçóes internacionais. Êsses problemas, aliás. cada vez mais complexos e técnicos, tendem a deslocar-se para o âmbito exclusivo do especialista.

O prestigio do Itamarati estaria assim ligado, não sòmente a sentimentos de futilidade que a "carrière" possa sugerir, mas sobretudo à natural inclinação do brasileiro para aplaudir e valorizar tudo o que, representando o nome do pais, concorra para aumentar-lhe a fôrça e a influência entre as demais nações.

É êsse, em geral, o comportamento do brasileito em face de outras manifestações da vida nacional e que bem pode explicar, até certo ponto, a atmosfera de reverência e respeitu de que é cercada a Casa de Rio Branco.

É verdade que no caso particular do Itamarati convém não esquecer o elemento histórico que o engrandece. As tradições, os feitos, as grandes "cartadas" de nossa diplomacia poaem ser dis- 
cutidos entre mestres e doutos, - mas o certo é que tudo isso enche de admiração o homem culto como o chamado homem da rua, apesar do anedotário e das picuinhas de que se fizeram alvo alguns dos nossos diplomatas.

Atestam-nos mais uma vez os recentes planos do govêrno sôbre a posição politica continental e universal do Brasil e que tanta repercussão lograram no pais e no exterior. A confiança, o estimulo, o aplauso com que se tem falado do Itamarati nesse episódio de fundamental importância para o destino das América:, é fato de fácil comprovação.

Cabe ao Itamarati a tarefa de procurar concretizá-los. Com uma equipe de homens competentes e devotados, nossa diplomacia tem sabido cumprir com êxito a sua missão, dentro das contingências e da realidade da vida internacional dos nossos dias. $\mathrm{O}$ atual panorama das relações internacionais pode, mesmo, ser propicio à atuação dos nossos diplomatas.

Dividido em dois blocos que se disputam a hegemonia e o contrôle exclusivo dessas relações, o mundo de hoje comporta, todavia, vastas áreas de indole ou tendência politico cultural semelhante e que preferem não aderir a um dos blocos em luta. Na África, na Ásia, na América do Sul, até mesmo na Europa, numerosos paises se constituem campo para uma ação diplomática esclarecida, que vise a um maior entendimento entre os povos desejosos de paz e prosperidade efetivas.

Foram e são ainda freqüentes criticas aos objetivos e métodos de nossa diplomacia. Para uns ela padece, antes de mais nada. de certo "estatismo" incompativel com o dinamismo e a celeridade dos fatos internacionais. Chamam-na de diplomacia contemplativa por excelência. Seu grande mal, para outros, reside no invariável e monótono comportamento contemporizador diante de problemas por vêzes de delicadas conseqüências e que a conduz a fáceis e apressados compromissos. E a diplomacia da rotina, do conservadorismo, ainda que honesto e bem inspirado.

A verdadeira e autêntica posição diplomática do Brasil talvez não esteja em nenhuma dessas duas atitudes. Os fatos internos e externos da vida nacional levam, naturalmente, a pensar numa posição de maior objetividade e de melhores oportunidades para o Brasil, no âmbito dos acontecimentos internacionais.

Êsse é, sem dúvida, o espirito que anima a chamada Operação Pan-Americana, ponto inicial de uma ofensiva diplomática 
inteligente e consciente dos seus objetivos, em boa hora formulada pelo Presidente da República. Pais em fase de um desenvolvimento promissor, com área geográfica, população, cultura não despreziveis, nossa politica exterior terá de refletir, necessàriamente, todos êsses anseios e esperanças que marcam nossa vida politica interna.

As contradições, os equivocos ou as frustrações poderão assinalar os primeiros passos da nossa diplomacia nesse sentido. Estamos, porém, convencidos de que não the faltará nem competência nem o indispensável patriotismo para tanto.

Com reduzidos recursos, aparelhagem antiquada e um quadro desfalcado para a sua missão, o Itamarati tem realizado trabalho de vulto para a projeção internacional do Brasil, sem embargo dessas deficiências. Há muito mais carência de instrumentos e de meios de ação do que pròpriamente espirito conservador na elaboração dos nossos planos de estratégia diplomática.

Estamos, por isso mesmo, certos de que, em breve, consumadas as reformas e as modificações solenemente anunciadas, o Itamarati saberá desenvolver uma ação diplomática consentânea com as realidades do nosso tempo. Com tarefas e objetivos bem definidos, pessoal altamente especializado, novas dotaçóes que possibilitem inclusive a extensão da ação diplomática a áreas até agora inacessiveis, nossos diplomatas se sentirão capacitados a agir com maior ênfase na defesa dos supremos interêsses do pais. 